\title{
The Monti di Pietà in the Middle Ages from a Privileged Point of View: the Marches
}

\author{
Roberto Lambertini
}

University of Macerata, Macerata, Italy

Received February 1 2018; Accepted February 282018

Abstract: Studies concerning the Monti di Pietà have quite a long tradition; in the past decades, however, this institution has been studied from new perspectives. After arguing in favor of the Marches (central Italy) as a privileged view angle on the phenomenon, the paper touches upon some complex relationships existing between political authorities and Observant Franciscan preachers, who campaigned in favor of the Monti on explicit invitation of local authorities. The question of the actual functioning of the Monti is also connected with the mechanisms of social inclusion and exclusion; the role of Jewish moneylenders, who were the major targets of Observant preaching in favor of the Monti, is also a key issue for the understanding of the institution.

Keywords: Monti di Pietà • Marches $\bullet$ Credit • Solidarity •Inclusion

\section{Introduction}

The main purpose of the current paper was to highlight some aspects of the history of Monti di Pietà that can be of some interest also to specialists of contemporary theories which tried to match market economy with concerns for social welfare. As the bibliography on the subject is very rich, and it would be impossible to take it into consideration with thoroughness, the author focuses particularly on examples from an Italian region, the Marches.

In the following sections, the author first argues in favor of his choice of the Marches as a privileged object of the paper. Second, he focuses upon the relationship existing between the preaching of Observant Friars and the institution of the Monti. Finally, the author devotes his attention to the consequences of foundations of the Monti and to the possibility of assessing the influence they exerted on the economy. Although this task is not easy to be accomplished, in a volume devoted to economia sociale and soziale Marktwirtschaft, this issue cannot be ignored.

\section{Why the Marches?}

The first reason for choosing the Marches is quantitative. Vittorio Meneghin (1986), an erudite historian who has been a specialist of the Monti, listed almost 50 foundations between the second half of the 15th century and the beginning of the 16th century. The Monti established in the Marches outnumbers by far those found in many other Italian regions, including Umbria, which is considered to be, so to speak, the cradle of the institution. The global figure for the Monti established in the first century of its existence was, according to Meneghin's survey, 241. Therefore, a good fifth of the Monti established in Italy in the period of time investigated by Meneghin was located in the Marches. This provides the scholar with a 
much wider basis for comparison: he/she can highlight similarities and differences between the development of the institution in different settings, from the larger cities of the region, such as Ancona (Massaccesi 1974), Fermo, Ascoli, and Urbino (Gheller 2009), to smaller towns, such as Monterubbiano or Morrovalle (Diletti 1991; Capriotti 2011).

A second reason is that, with the only exception of James of the Marches (a.k.a. James of Monteprandone, cf., e.g., Serpico 2009) and the less well-known Marco da Montegallo (Mercatili Indelicato 2001), the Observant Franciscan preachers who campaigned in favor of the new institution were, so to speak, second-row figures, such as Domenico da Leonessa (Casagrande 1991), so that we can have a grasp of the developments in a more ordinary situation, independently from the influence of great charismatic figures, such as Bernardino da Feltre (Checcoli 2008).

One has to acknowledge that the debate among historians about the possible chronological precedence of Ascoli Piceno over Perugia, that divided scholars from Umbria and the Marches in the past decades, was too much influenced by parochialism (Pagnani 1982). It helped, nevertheless, to shed more light on the fact that prior to 1462 , the year in which the first Monte was established, there were already attempts at tackling the issue of the need of small loans. At the same time, the semantics of the phrase itself, Monte di Pietà, was still fluid (Muzzarelli 2001, pp. 69-71), before being connected with precision with an institution that has been defined by Wood, a "public pawnshop for the poor" (Wood 2002, p. 203). Kirshner (1983) and Armstrong (1999) devoted important investigations to another institution that was also called, in the same places, "Monte," but had in reality to do with forced loans imposed by the civic administration on its citizens. With such Monti del Comune that started to exist much earlier than the Monti di Pietà, however, the civic community acted as a public money borrower, not as moneylender (Conetti 2010). Muzzarelli was able to show that the Monti di Pietà were also the final result of various attempts to make credit available to people who needed it, but could not afford the costs of the money market in the late Middle Ages (Muzzarelli 2001, pp. 11-143).

Finally, the Marches offered evidence of the coexistence, at least for the final decades of the 15th century, of two different models of Monte. One, supported in particular by Marco da Montegallo, made available small loans on the security of pawns, without any additional charge. Obviously, this model tried to counter the charge, soon leveled by the adversaries of the new institution, to practice usury while pretending fighting against it. The other model, which was approved by the majority of the Observant Franciscan Friars at the end, foresaw a charge, which was called "merito" or "salario," and was interpreted as a participation in the expenses necessary to assure the functioning of the institution (Ghinato 1972; Bonazzoli 1991).

\section{The "treasure" of the civitas}

As already mentioned, it is well known that the institution of the Monti di Pietà is an initiative of the Observant Franciscan Friars. They preached in favor of the new initiative, played a pivotal role in drafting the statutes of the Monti, and defended the institution against its critics. From this point of view, the Monti were essentially a "Franciscan" invention: not by chance many experts see a connection between the Monti and the Franciscans' attitude toward economy, that has been called several times "Franciscan economics" (e.g., Todeschini 1976; Langholm 1992 and the assessment by Evangelisti 2016, pp. 225-228); thus, we do not need to delve into the learned debate that has been developed about this issue (Lambertini 2016). Rather, it is important to avoid the risk of inferring from this protagonism of the Franciscan Observants that they were the sole actors of the initiative. There were some Dominicans who also played an important role. Girolamo Savonarola was probably the most famous Dominican founder of a Monte (Muzzarelli 2001, pp. 28-29, 36-37), but the Marches know the example of Giovanni da Pistoia in Ripatransone (Pellegrini 2007). More importantly, the Monti were not a "Franciscan" invention in the sense that the Franciscan Order (or better its Observant branch) put the Monte into existence and kept its development under control. On the contrary, the intervention of the Franciscans was limited to preaching and counseling. The actual foundation depended on the local administration. In most cases, the Friars were invited to preach by the local authorities (who, despite the fact that the Marches belonged to the Papal State, still enjoyed in the second half of Quattrocento spaces of autonomy) who had already taken into consideration the possibility of establishing a Monte. They held a series of sermons in favor of the Monte and offered their help in drafting the statutes (usually using a preexisting model), which were adapted to the local situation. The town council had not only approved formally the initiative but also found the capital necessary for starting the Monte. The preachers usually exhort of course their audience not only to give the necessary support to the Monte by expressing their consent but also by making donations in favor of the new institution. Still, in most cases, the most substantial amount was found by finalizing, for this purpose, a source of income of the commune, most usually a tax or 
a rent deriving from possessions belonging to the community. It was the government of the local community that appointed the officers in charge with the various aspects of the administration of the commune, bookkeeping, evaluation of pawns, and auction of pawns not redeemed by the borrowers. The authorities of the commune also examined the performance of the officers and decided whether they had met the expectations of the community. If not, they were usually fined, if not condemned to more severe punishments. Local authorities could decide that the Monte had to cease its activities and that it may be reopened (many examples that followed this pattern were very well summarized in Muzzarelli 2001, pp. 11-86). The Monte was perceived as a civic institution that in many cases the civic council did not hesitate to limit or even to suspend its activity to invest its financial resources in a different initiative (e.g., restoring the city walls or building a port), which was deemed to be more vital for the community in that moment. The case of Recanati is one among many others: it was found that, for the first time in 1468 , by the end of the century it was in such a miserable financial situation that it was closed down. In 1507, local authorities decided to start anew, invited another Franciscan preacher, and issued new statutes (Pagnani 1982; Bartolacci forthcoming).

It would be anachronistic to project modern categories into the situation of Quattrocento and Cinquecento, where the distinction between ecclesiastical and civic spheres was not clear as we think it is the case for nowadays society at least in some parts of the world; still, it should be remarked that the Monte, while religious in inspiration, was not an ecclesiastical institution in the strict sense of the term. II "Thesoro" della città, which is the title of a book by Fornasari (1993) who devoted to the Monte di Pietà of Bologna, could not have been more appropriate. Like many other civic institutions, the Monti could fall prey of corrupted officials, who profited in various ways of their privileged position. Very recently, Righi (2017a) investigated the norms that, in the statutes of the Monti, were aimed at preventing embezzlement. The Marches provide rich evidence, concerning norms and practice, of such problems afflicting the administration of the Monti. Interesting results came also from a first sounding about evaluation and preservation of pawns: the pawns were sometimes overestimated to the advantage of the borrower with the consequence that the institution sold the pawned objects at a loss which were not redeemed (Lambertini 2017).

The history of the Monti had therefore both successes and failures: only some of them reached the level of important financial institutions. Generally speaking, the activity of lending small sums at a law interest rate on the security of pawns was not in itself sustainable: the Monti needed to be financed in other ways if they were to preserve their capital (although focused on Bologna; Carboni 2014, pp. 61-143). From time to time, the community could invest in the Monte, but greater or smaller private bequests often constituted the main source of income of the institution. Moreover, the Monti were open not only to donations but also to deposits. For the more recent historiography, the debate whether the Monti at their origin were essentially a charity or a sort of bank is in itself superseded: their identity, as Bonazzoli put it, consists exactly in the fact that they provided credit for welfare purposes (Bonazzoli 1991, pp. 86-87).

\section{Mission impossible?}

Zdekauer, a Moravian exile who had found a secure haven at the University of Macerata (in the Marches) in the second half of the 19th century, studied the Monte di Pietà established in Macerata (Zdekauer 1900, but see Pirani 2016): in his study, he raised a doubt about the capacity of the Monti to really fulfill their mission. Zdekauer was very skeptical and maintained that the institution never succeeded in helping the poor, but rather served the interests of some merchants who could have access to loans at a very favorable rate for their own business. As a matter of fact, the statutes of the Monti inform us about exclusions: implicitly (and rather obviously), everybody was excluded who cannot give a pawn as security; the pawn should have had a value that significantly exceeded (usually by a third) the sum borrowed. From the beginning, therefore, the action of the Monti was not aimed at the miserables but at the less poor among the poor. People of this kind, although in need of credit, were expected to be able to return the borrowed sum in due time. At any rate, such less poor among the poor could give to the Monte goods that as pawns could be transformed into liquidity if they failed to repay the loan. A thorough, unbiased investigation based on the lists of pawns accepted seemed to confirm this social profile of the people who, generally speaking, benefited from the services of the Monte (for the Marches, e.g., Trubbiani 2001). Moreover, those not belonging to the community that established the Monte and supported it were excluded: newcomers, or even specific ethnic groups. In the Marches, the statutes were mentioned as immigrants from Albania and Slavonia, although this ban was sometimes lifted in later versions of the statutes, provided that they could show to have been residents for a spell of time deemed to be sufficient (Pagnani 1982; Bartolacci forthcoming).

There is, however, a more radical form of exclusion that is connected to the institution of the Monti. As it is well known, one of the main issues of the propaganda in favor of the Monti was a full-scale attack on the Jewish 
communities and their financial activities (Fornasari 1999; Todeschini 2018). Preaching campaigns in favor of the Montes were accompanied by furious attacks, on part of the Observant Friars, on Jewish moneylenders. According to these preachers, the poor Christians were to drown in the abyss of Jewish usury if the Monte could not rescue them. Depicted as parasites sucking up Christian blood, the Jews, who in fact played a significant role in the money market especially in central Italy, were exposed not only to the risk of losing their source of income but also to serious personal dangers as a consequence of the sermons aimed at persuading the citizenship of the necessity of establishing a Monte (Muzzarelli 2001, pp.250-258, about Bernardino da Feltre see also Melchiorre 2012). Some scholars were able to show that the institution of the Monti was not able alone to meet the demand of credit that found satisfaction from Jewish moneylenders (Bonazzoli 1989, 1991, 1999), to the effect that the Monti and Jewish banchi coexisted for many decades, for example, in the Marches. According to Todeschini (2016),

\section{References}

Armstrong L., The politics of usury in Trecento Florence: the Quaestio de Monte of Francesco da Empoli, Med Stud, 61, 1-44, 1999.

Bartolacci A., Per la storia di un Monte di Pietà marchigiano: gli statuti di Recanati del 1507, Picenum Seraphicum, 31, forthcoming.

Bonazzoli V., II prestito ebraico nelle economie cittadine della Marche fra '200 e '400, Ancona, 1989.

Bonazzoli V., Monti di pietà e politica economica delle città nelle Marche alla fine del '400, In: Banchi pubblici, banchi privati e monti di Pietà nell'Europa preindustriale, Atti Società Ligure di Storia Patria, 31, 565-589, 1991.

Bonazzoli V., Banchi ebraici, Monti di pietà, Monti frumentari in area umbro-marchigiana: un insieme di temi aperti, Fornasari, 181-214, 1999.

Capriotti G., Gestire il denaro, gestire la salvezza. Tre immagini a sostegno del Monte di Pietà: Marco da Montegallo, Lorenzo d'Alessandro e Vittore Crivelli, II Capitale Culturale. Stud Value Cult Herit, 2, 13-40, 2011.

Carboni M., Muzzarelli M.G., Zamagni S., Sacri recinti del credito, Sedi e storie dei Monti di pietà in Emilia Romagna, Venezia, 2005.

Carboni M., II credito disciplinato. II Monte di Pietà di Bologna in età barocca, Bologna, 2014.

Casagrande C., Domenico da Leonessa, In: Dizionario Biografico degli Italiani, Dizionario-Biografico, however, in the long run, the early modern Christian society, at least in Italy, succeeded in driving away the Jews from the money market: the Monti were a very efficient tool for this purpose and belonged to an overall strategy. They were, on the other hand, rooted in the Franciscan tradition of economic thought, in which the overall importance of the well-being of the community implied necessarily the expulsion of everybody who did not properly belonged to it. From the perspective of Todeschini, therefore, the appeal to the Christian duty of helping the poor was largely instrumental to the marginalization of the Jewish community. Other historians tend to emphasize the fact that with the experiment of the Monti the civic administrations of late Medieval and early Modern Italy tried to influence the credit market with an instrument that tried to be, at the same time, solidaristic and economically sustainable (Prodi 1982; Carboni et al. 2005). This is probably what interests us most in the Monti nowadays, although their history is also a warning against all attempts at grounding solidarity on exclusion.

1991. Available at: http://www.treccani.it/enciclopedia/domenico-da-leonessa (last visit 15/02/2018).

Checcoli I. (Ed.), B. Guslino. La vita del beato Bernardino da Feltre, Bologna, 2008.

Conetti M., Un'etica per i prestiti pubblici. Teologia, canonistica e monti del Comune, In: Lambertini R., Sileo L. (Eds.), I Beni di questo mondo. Teorie etico-economiche nel laboratorio dell'Europa medievale, Porto, 231-252, 2010.

Diletti P., Per la storia di Morrovalle: contributi e ricerche, Morrovalle, 1991.

Evangelisti P., II pensiero economico nel Medioevo. Ricchezza, povertà, mercato e moneta, Roma, 2016.

Fornasari M., II thesoro della città. II monte di pietà e l'economia bolognese nei secoli XV e XVI, Bologna, 1993.

Fornasari M., Monti di pietà e presenza ebraica in Italia (secoli XV-XVIII), Roma, 1999.

Gheller G., I capitoli del monte di pietà di Urbino del 1468 e le loro specificità nell'orizzonte delle coeve fondazioni di Monti Pii, In: Carboni M., Muzzarelli M.G. (Eds.), I Monti di Pietà fra teoria e prassi. Quattro casi esemplari, Bologna, 1-65, 2009.

Ghinato A., I Monti di Pietà istituzione francescana, Picenum Seraphicum, 9, 7-62, 1972.

Kirshner J., Storm over the "Monte Comune": genesis of the moral controversy over the public debt of Florence, Arch Fratrum Praedicatorum, 53, 219-276, 1983. 
Lambertini R., Economia Francescana. Momenti del percorso di un concetto storiografico Divus Thomas, 171-196, 2016.

Lambertini R., Pegno, amicizia, ammanco. Primi sondaggi sui monti marchigiani, Righi, 277-291, 2017.

Langholm O., Economics in the Medieval Schools, wealth, exchange, value money and usury according to the Paris thelogical tradition, Brill, Leiden, New York, Köln, 1992.

Massaccesi V., II Monte di Pietà di Ancona, dalle origini alla fine del XVII secolo, Annali della Facoltà di Lettere e Filosofia dell'Università di Macerata, 7, 55-95, 1974.

Melchiorre M., A un cenno del suo dito. Fra Bernardino da Feltre (1439-1494) e gli ebrei, Milano, Unicopli, 2012.

Meneghin V., I Monti di Pietà in Italia dal 1462 al 1562, LIEF, Vicenza, 1986.

Mercatili Indelicato E., Vita e opere di Marco dal Monte Santa Maria in Gallo, ISSM “Cecco d'Ascoli”, Ascoli Piceno, 2001.

Muzzarelli M.G., II denaro e la salvezza. L'invenzione del Monte di Pietà, II Mulino, Bologna, 2001.

Pagnani G., II Monte di Pietà di Fermo e Recanati e la priorità di quello di Ascoli, Atti e memorie della deputazione di storia patria per le Marche, 87, 435493, 1982.

Pellegrini L., II convento di Ripatransone e l'apostolato di Giovanni da Pistoia: un saggio sulle Marche dei Domenicani tra XIII e XV secolo, Studia picena, 72, 43-82, 2007.
Pirani F. (Ed.), Ludovico Zdekauer. Discipline storiche e innovazione tra Otto e Novecento, Deputazione di Storia Patria per le Marche, Livi, Ancona-Fermo, 2016.

Prodi P., La nascita die Monti di Pietà tra solidarismo cristiano e logica del profitto, Annali dell'Istituto storio italo-germanico di Trento, 7, 211-224, 1982.

Righi L. (Ed.), Storie di frodi. Intacchi, malversazioni e furti nei Monti di pietà e negli istituti caritatevoli tra Medioevo ed Età moderna, II Mulino, Bologna, 2017.

Righi L., Prevenire le frodi: legislazione e amministrazione dei primi monti di Pietà, in Righi 2017, 259-275, 2017a.

Serpico F. (Ed.), Biografia e Agiografia di San Giacomo della Marca. Atti del Convegno Internazionale di Studi, Monteprandone, SISMEL, Firenze, 2009.

Todeschini G., Oeconomica francescana I: proposte di una nuova lettura delle fonti dell'etica economica medievale, Rivista di storia e letteratura religiosa, 12, 15-77, 1976.

Todeschini G., La banca e il ghetto. Una storia italiana, Laterza, Roma-Bari, 2016.

Todeschini, G., Gli ebrei nell'Italia medievale, Carocci, Roma, 2018.

Trubbiani A., II Monte di Pietà di Montecassiano, Picenum Seraphicum, 20, 193-248, 2001.

Wood D., Medieval economic thought, Cambridge University Press, Cambridge et alibi, 2002.

Zdekauer L., La fondazione del Monte Pio di Macerata ed i primordi della sua gestione (1469-1510) con il testo dei "capitoli"del 1468, Bocca, Torino, 1900. 
